\title{
Problem alkoholu w życiu człowieka i ekologia ludzka
}

Tytułowe pojęcie alkoholu (alkoholizmu) mieści się w obszarze znaczeniowym podanym w Encyklopedii katolickiej², a ekologię ludzką (ang. human ecology) należy rozumieć jako syntezę nauk

Dr hab. Jerzy Brusiło OFMConv - wykładowca w Katedrze Teologii Pastoralnej i w Międzywydziałowym Instytucie Bioetyki Uniwersytetu Papieskiego Jana Pawła II w Krakowie; współpracuje z Instytutem Ochrony Przyrody PAN w Krakowie iz Uniwersytetem Rolniczym w Krakowie. Krajowy Duszpasterz Lekarzy Weterynarii, współautor prac zespołu Konferencji Episkopatu Polski d/s ekologicznego Programu Duszpasterskiego.

2 „Wyróżnia się: 1) Umiarkowane spożywanie alkoholu w przyjętych obyczajowo okolicznościach (spotkania towarzyskie, zabawy, uroczystości), które nie pociąga za sobą szkodliwych następstw fizycznych, psychicznych i społecznych. 2) Nadużycie i nadużywanie sporadyczne alkoholu, które prowadzi do szkodliwych następstw (zatrucie) oraz jest przyczyną następstw i ekscesów natury moralnej popełnianych w czasie odurzenia alkoholowego. 3) Alkoholizm nałogowy, gdy częste nadużywanie prowadzi do chorobliwego przyzwyczajenia do alkoholu i niemożności zaprzestania picia pomimo licznych komplikacji osobistych i społecznych przez nie powodowanych. 4) Alkoholizm przewlekły, kiedy nałogowemu używaniu alkoholu towarzyszą nieodwracalne często zmiany somatyczne (marskość wątroby, zapalenie wielonerwowe, nieżyty przewodu pokarmowego oraz dróg oddechowych i in.), zmiany psychiczne (psychodegeneracja alkoholowa i zaburzenia psychiczne) oraz zmiany w sytuacji spo- 
przyrodniczych, antropologii filozoficznej i teologii, z podkreśleniem godności i znaczenia osoby ludzkiej jako centralnego punktu świata stworzonego oraz z zaznaczeniem, że jest ona stworzeniem Bożym („obrazem Stwórcy”, Rdz 1, 27) odkupionym przez Chrystusa ${ }^{3}$.

Na potrzeby tego opracowania trzeba przyjąć, że alkohol stanowi nieodłączną część rzeczywistości ludzkiej (nadużywany lub nie), kultury, społeczeństwa i codziennej praktyki żywieniowej. Nie jest to wprawdzie niezbędny dla życia napój, jak bezalkoholowe elementy zrównoważonej diety, ale jego dostępność pod różnymi postaciami nasuwa porównanie go do takich składników pokarmowych jak cukier, sól i tłuszcz, które nadużywane stanowią dziś w krajach rozwiniętych (zasobnych w pożywienie) problem ekonomiczny i zdrowot$n y^{4}$, mimo iż również są one zwyczajnym składnikiem żywieniowym człowieka.

Nawet w przeglądzie korzyści, jakie odnotowuje historia umiarkowanego, kulturalnego spożycia różnych form napojów alkoholowych $^{5}$, i w sprowadzeniu negatywnego wpływu alkoholizmu wyłącznie na poziom biologiczny czy socjobiologiczny we współczesnych, złożonych problemach ekologicznych, związanych z osobą ludzką, pojawia się pytanie o antropologiczne i etyczne relacje między spożyciem alkoholu (nadużywaniem go) a przyrodniczym, filozoficznym i teologicznym znaczeniem osoby ludzkiej wśród stworzenia (ekologia ludzka). Co jest najważniejsze w tej relacji i w jakich

łecznej alkoholika (degradacja)". A. Sułkowski, Alkoholizm, [w:] Encyklopedia katolicka, t. I, red. F. Gryglewicz, R. Łukaszyk, Z. Sułkowski, Lublin 1973, kol. 373.

3 Por. M. Wyrostkiewicz, Ekologia ludzka. Osoba i jej środowisko z perspektywy teologicznomoralnej, Lublin 2007, s. 54-55.

4 Por. M. Moss, Cukier, sól, tłuszcz. Jak uzależniają nas koncerny spożywcze, tłum. P. Cieślak, Łódź 2014.

5 Por. I. Gately, Kulturowa historia alkoholu, tłum. A. Kunicka, Warszawa 2011, s. 593594. 
warunkach problem alkoholizmu może znaleźć rozwiązanie w ekologii ludzkiej?

\section{Człowiek i alkohol w naturalnym środowisku przyrodniczym i społecznym}

Zarówno osoba ludzka, jak i alkohol etylowy (jako związek chemiczny $\left.{ }^{6}\right)$ są częścią naturalnego świata przyrody, wchodzą ze sobą w naturalne relacje biochemiczne i fizjologiczne. Człowiek spożywał tę substancję w wielu jej formach od najdawniejszych czasów, mając przy tym różne motywacje. Ekologia jako nauka „zajmująca się badaniem wzajemnych oddziaływań między organizmami a ich środowiskiem" abiotycznym i biotycznym ${ }^{7}$ lub „nauka o organizmach w powiązaniu z szeroko rozumianym środowiskiem" ${ }^{8}$ może zatem również podejmować badania nad funkcjami i uwarunkowaniami działania alkoholu na organizmy żywe w środowisku przyrodniczym. Chociaż w ekologii behawioralnej, fizjologicznej, ewolucyjnej, molekularnej, populacyjnej i innych nie mówi się o „ekologii alkoholu” jako nauce o działaniu tego związku chemicznego na środowisko naturalne, to już na szerszym tle ekologii człowieka można mówić „o gatunku Homo sapiens i jego kulturze jako dynamicznym komponencie ekosystemów” w kontekście alkoholu, tytoniu i innych używek, narkotyków, używania leków i różnorakich aktywnych substancji syntetycznych, które znacznie de-

6 Etanol $\left(\mathrm{C}_{2} \mathrm{H}_{5} \mathrm{OH}\right)$, najbardziej znany spośród dużej grupy związków organicznych charakteryzujących się występowaniem w składzie chemicznym jednej lub kilku grup hydroksylowych $(-\mathrm{OH})$, jest bezbarwną, łatwopalną, wonną cieczą, łatwo mieszającą się z wodą, działającą dezynfekująco i przeciwgnilnie. Por. I. Niewiadomska, M. Sikorska-Głodowicz, Alkohol, Lublin 2004, s. 7-8 (Uzależnienia. Fakty i Mity).

7 Por. A. Mackenzie, A. S. Ball, S. R. Virdee, Ekologia, tłum. M. Kozakiewicz, K. Dmowski, A. Kozakiewicz, wyd. 2 zm., Warszawa 2005, s. 1 (Krótkie Wykłady).

8 P. Trojan, Ekologia, [w:] Wielka encyklopedia PWN, red. J. Wojnowski, Warszawa 2002, s. 112. 
terminują rozwój człowieka oraz jego zachowania, przemianę materii, stan zdrowia i inne właściwości organizmu i psychiki.

Różne leki, zioła, trucizny i związki chemiczne pochodzenia naturalnego towarzyszyły człowiekowi od prehistorii, ale dopiero od połowy XX wieku skala ostrych zatruć substancjami chemicznymi produkowanymi przez cywilizację zaczęła lawinowo rosnąć. Chemizacja życia, dostęp do środków chemicznych zawierających różne alkohole (w tym przede wszystkim interesujący nas alkohol etylowy) w konserwacji, barwieniu, w środkach czyszczących, rozpuszczalnikach, środkach ochrony roślin, w lekach i innych produktach syntetycznych, w przemyśle chemicznym, farmaceutycznym, kosmetycznym i rolnictwie wywołuje coraz częściej poważne zatrucia występujące przypadkowo lub powodowane celowo (samobójstwa). Do tego dochodzą jeszcze problemy cywilizacyjne przejawiające się w narastaniu nerwic, stresu, depresji i innych chorób psychicznych, co wiąże się z kolei z masowym używaniem środków uspokajających, nasennych, psychotropowych, narkotycznych oraz ze zwiększonym spożyciem alkoholu (niejednokrotnie jednocześnie z lekarstwami) ${ }^{10}$.

Nie ma uniwersalnej normy, jeśli chodzi o czas przyjmowania i dawkę spożytego alkoholu, nie ma jednakowego dla wszystkich pijących mechanizmu uzależnienia, gdy z okazjonalnego, sporadycznego użycia alkoholu w zabawie, odpoczynku i przyjemności, z leczniczego wpływu na organizm ludzki przechodzi się do nadużycia alkoholu i uzależnienia od niego. Opisuje tę granicę szereg modeli biologicznych i psychospołecznych z ciągle jeszcze nierozstrzygniętymi kwestiami: po pierwsze „wyróżnieniu fizycznej i/lub psychicznej specyfiki jednostki podatnej na uzależnienie od alkoholu z uwzględnieniem modyfikującego wpływu

9 Por. N. Wolański, Ekologia człowieka. Podstawy ochrony środowiska i zdrowia człowieka, t. 1, Wrażliwość na czynniki środowiska i biologiczne zmiany przystosowawcze, Warszawa 2006, s. 4.

10 Por. A. Wiernikowski, W sferze trucizn, [w:] Człowiek przeciwko sobie?, red. A. Lecikowa, wyd. 2 zm. i uzup., Warszawa 1986, s. 405-406. 
środowiska społecznego” i po drugie: „wskazanie na takie farmakologiczne właściwości alkoholu, które w interakcji z organizmami żywymi prowadzą do psychicznego i/lub fizycznego uzależnienia" ${ }^{11}$.

Niewątpliwie związek różnych biologicznych substancji aktywnych, powodujących uzależnienia, z życiem i rozwojem człowieka jest widoczny w badaniach nad wpływem alkoholu na dzieci i młodzież w zależności od ich faz rozwoju, ról społecznych, wychowania, wpływu środowiska, religijności i psychiki. Okazuje się, że pierwsze kontakty z alkoholem u dzieci występują najczęściej już od 12 roku życia a od 14 do 21 roku życia procent osób regularnie pijących i upijających się szybko wzrasta ${ }^{12}$. Istnieją czynniki, które bez względu na obszar kulturowy, klimat i kraj występują w podobnym natężeniu i dynamice ${ }^{13}$. Wspomniane badania wskazują na to, że od dzieciństwa człowiek jest narażony na szereg zagrożeń somatycznych, psychicznych i społecznych ${ }^{14}$, które godzą w jego godność - godność

11 L. Cierpiałkowska, Alkoholizm. Przyczyny-leczenie - profilaktyka, Poznań 2001, S. 53.

12 Por. M. Radochoński, A. Radochońska, Rozwój uzależnienia od substancji psychoaktywnych z perspektywy cyklu życia, [w:] Człowiek w obliczu zniewolenia. Od zagrożeń do nadziei, red. Z. B. Gaś, Lublin 2012, s. 17.

13 Nie chodzi tu jednak o wymiar globalny, ponieważ w niektórych częściach świata tabu kulturowe, zwyczaje abstynenckie i zakazy religii znacznie ograniczają dostęp dzieci i młodzieży do alkoholu. Por. V. B. Faden, Trends in initiation of alcohol use in United States 1975 to 2003, „Alcoholism. Clinical and Experimental Research” 30 (2006), s. 1011-1022; za: M. Radochoński, A. Radochońska, Rozwój uzależnienia..., dz. cyt., s. 17.

14 „Zależności, jakie tu występują, są dwukierunkowe, co oznacza, że pewne czynniki rozwoju wpływają na ryzyko uzależnienia się od środków psychoaktywnych, jak również uzależnienie wpływa na późniejszy rozwój jednostki. Do czynników rozwoju mogących sprzyjać uzależnieniu należą m.in. niekorzystne cechy osobowości, determinujące określone zaburzenia zachowania (np. lęk, depresja, impulsywność, wstydliwość), czynniki środowiska rodzinnego (np. przemoc wobec dziecka, zaniedbywanie lub odrzucenie go, wczesne narażenie na kontakt ze środkami psychoaktywnymi), relacje z rówieśnikami i środowiskiem lokalnym 
osoby ludzkiej jako najważniejszej części świata stworzonego, odkupionego przez Chrystusa.

Zagrożenia te nigdy nie zmieniają natury ludzkiej, ale sprawiają, że tym bardziej natarczywe staje się pytanie o relacje między spożyciem i nadużywaniem alkoholu a ekologią ludzką. Nietrzeźwy człowiek (nałogowy alkoholik) to nie to samo co miś koala odurzony sfermentowanym sokiem eukaliptusa, ponieważ człowiek pijący alkohol lub uzależniony od niego jest w swojej wolności i rozumności zawsze kimś więcej niż jakikolwiek inny organizm biologiczny. Stąd problem alkoholu, narkotyku czy nadużywanego leku nie mieści się tylko w zakresie szeroko pojętej ekologii, samych faktów zwyczajnego (np. leczniczego) używania alkoholu czy złożonych czynników nałogowego nadużywania go w relacji do środowiska i innych oddziaływań abiotycznych i biotycznych.

\section{Alkohol-środowisko: ekologia człowieka czy ekologia ludzka?}

W analizie biologicznego oddziaływania alkoholu na człowieka, gdy alkohol i człowiek są częścią tej samej przyrody stworzonej, nie tylko powinniśmy dostrzec bezpośrednie szkody, jakie nadużywanie tej substancji przynosi jednostce. Zauważa się również, że w formie masowego produktu przemysłowego alkohol może chemicznie zanieczyścić środowisko, niszczyć jego żywe elementy ${ }^{15}$. W każdym

(np. eksperymentowanie z alkoholem, poszukiwanie akceptacji, szkodliwe tradycje), interakcja czynników genetycznych i środowiskowych, nierównomierne dojrzewanie struktur mózgowych (np. opóźnienie dojrzewania kory przedczołowej utrudniające kontrolę emocji i zachowania), różnice w podatności na działanie środków psychoaktywnych (np. część młodzieży wykazuje mniejszą wrażliwość na awersyjne skutki upicia się, co skłania ją do dalszego eksperymentowania)”. M. Radochoński, A. Radochońska, Rozwój uzależnienia..., dz. cyt. 
przypadku interesuje nas przede wszystkim uzależniony człowiek jako część zatrutego środowiska naturalnego, rodzinnego i społecznego. Ludzkość i jej cywilizacja, w rosnącej populacji, z ogromną konsumpcją w imię postępu, z niszczącymi możliwościami na skalę globalną, jako część środowiska naturalnego i przyczyna kryzysu ekologicznego, jest jednocześnie głównym czynnikiem decydującym o przyszłości całej przyrody i pierwszą ofiarą konsumpcjonizmu jako nadmiernego gromadzenia posiadania i wykorzystywania dóbr materialnych. Nieopanowana konsumpcja słusznie jest postrzegana jako forma uzależnienia i zniewolenia człowieka ${ }^{16}$, nie tylko dla niego samego, ale w wymiarze szerszym. Dlatego alkoholizm stanowi problem potrójnie trudny do rozwiązania - jako czynnik wpływający na stan środowiska przyrodniczego, jako część problemu społecznego w uzależniającej konsumpcji poszczególnych osób i - w nadmiarze - jako używka prowadząca do nałogu konkretnego człowieka. Biorąc pod uwagę choćby tylko ten ostatni problem, trudno ogarnąć w tym miejscu wszystkie jego aspekty, ale obraz osoby ludzkiej nie powinien być oderwany od wielu złożonych kontekstów, które można wstępnie umieścić w obszarze ekologii człowieka i ekologii ludzkiej. Który obszar będzie bardziej adekwatny?

Alkoholizm i nadużywanie innych substancji psychoaktywnych jest od dawna przedmiotem wielopłaszczyznowych badań analitycznych i porównawczych. Obecnie ten problem w badaniach naukowych stanowi najczęściej domenę psychologii i socjologii, czasem medycyny i toksykologii, ale zawsze zainteresowanie przeciwdziałaniem nałogom najbardziej skupia się na człowieku jako

16 Por. A. Słaboń, Ewangelizacja postawy konsumpcyjnej, www.orrk.pl/index.php/ kongresy-tematyczne/kultura/ruchy-a-kultura/434-ewangelizacja-postawykonsumpcyjnej (17.09.2014); D. Strzyżewska, Zagrożenia środowiska wynikające z nadmiernej konsumpcji, „Studia Ecologiae et Bioethicae” 7 (2009) nr 2, S. 163. 
istocie niezwykle złożonej w swym temperamencie i emocjach ${ }^{17}$, istocie psychicznej i duchowej, wymagającej pomocy, szukającej wsparcia i sposobu przezwyciężenia sytuacji „zniewolenia, czyli kogoś, kto czyni to, czego nie chce, gdyż dotąd czynił to, co chciał"18. Na jego decyzje wpływają takie czynniki jak osobowość, relacje rodzinne, problemy zawodowe, możliwości w dostępie do używek, a nawet uwarunkowania kulturowe, warunki klimatyczne i cechy szeroko pojętego środowiska życia ludzi pijących alkohol i uzależnionych od tej substancji. Z jednej strony te wszystkie okoliczności powstawania uzależnienia od alkoholu mogą sprzyjać pogłębianiu się nałogu w każdej fazie życia ludzkiego, ale z drugiej mogą one zadziałać korzystnie w wyzwalaniu się z uzależnień i trwaniu w abstynencji, jeżeli uwzględnimy jeszcze w człowieku sferę jego godności, wolności ${ }^{19}$ i religijności.

Lepsze zrozumienie mechanizmów uzależnienia wymaga nie tylko wzięcia pod uwagę wymiarów biologicznego, poznawczego, emocjonalnego i społecznego ${ }^{20}$, ale też wymiaru ekologicznego, jeśli ekologię będziemy rozumieć nie tylko jako ekologię człowieka ${ }^{21}$, ale bardziej jako ekologię ludzką (w znaczeniu podanym na początku

Por. J. Chodkiewicz, Rola temperamentu i charakteru w ujęciu Roberta Cloningera w przebiegu i efektach terapii mężczyzn uzależnionych od alkoholu, [w:] Wybrane zagadnienia psychologii alkoholizmu, red. ]. Chodkiewicz, K. Gąsior, Warszawa 2013, s. 66-74.

Z. B. Gaś, Wstęp, [w:] Człowiek wobliczu zniewolenia, dz. cyt., s. 9. Szersze omówienie antropologii ludzkich uzależnień można znaleźć w artykule: ]. Brusiło, Palenie tytoniu - antropologiczne ujęcie ludzkich uzależnień, „Przegląd Lekarski" 62 (2005) nr 10, s. 947-953. Także w etiologii, terapii i profilaktyce uzależnienia od alkoholu. Por. M. Radochoński, A. Radochońska, Rozwój uzależnienia..., dz. cyt., s. 18, 21. „Dziedzina interdyscyplinarna, z pogranicza ekologii i antropologii, badająca człowieka jako gatunek biologiczny w jego związkach ze środowiskiem oraz zależnościach wewnątrzgatunkowych i międzypopulacyjnych". K. Kaczanowski, Ekologia człowieka, [w:] Wielka encyklopedia PWN, dz. cyt., s. 114. 
artykułu). Wspomniany potrójny problem alkoholizmu może być tutaj potraktowany głębiej, ponieważ w ekologii ludzkiej, która

zajmuje się też badaniem i opisywaniem naturalnego środowiska osoby ludzkiej, czyli otoczenia, które pozwala jej żyć i realizować swoje powołanie, jakim jest rozwój integralny [...] W tak rozumianym środowisku można wyróżnić trzy podstawowe elementy. Są to: przyroda, społeczeństwo i sama osoba ${ }^{22}$.

\section{Od ekologii ludzkiej do profilaktyki uzależnienia od alkoholu}

Alkohol jako czynnik wpływający na stan środowiska przyrodniczego, jako część problemu społecznego w uzależniającej konsumpcji poszczególnych osób i jako używka prowadząca do nałogu konkretnego człowieka rzeczywiście najbardziej dotyka problemu osoby i jej środowiska, a dokładniej - stosunku osoby ludzkiej w jej złożoności i niezwykłości do środowiska naturalnego. Pojawia się tutaj chyba najważniejszy element ekologii ludzkiej, który w kontekście alkoholu jako naturalnej części środowiska ludzkiego i w kontekście alkoholizmu jako zagrożenia dla środowiska ludzkiego odróżnia ekologię ludzką (ekologię osoby) od ekologii człowieka. Chodzi o normatywny charakter ekologii ludzkiej, posiadającej w swej strukturze zdolność do moralnej oceny postępowania człowieka wobec przyrody, wobec społeczności (rodziny) i wobec samego siebie, swojego życia i zdrowia. Moralność osoby ludzkiej może „odkryć możliwości uniknięcia zagrożeń lub zaproponować drogi wyjścia z istniejącego już kryzysu ekologicznego"23. Nie gwarantuje tego nawet pogłębione ujęcie ekologii człowieka, mimo iż określa go holistycznie, interdyscyplinarnie

\footnotetext{
22 M. Wyrostkiewicz, Ekologia ludzka, dz. cyt., s. 55.

23 M. Wyrostkiewicz, Ekologia ludzka, dz. cyt., s. 55
} 
i kulturowo (ekologia kultury) ${ }^{24}$. Biologiczne, naturalne, relacyjne, a nawet humanistyczne podejście do człowieka w przyrodzie nie ma wymiaru moralnego - bardzo dziś potrzebnego - w rozumieniu roli wolnej, rozumnej osoby ludzkiej w podejściu do środowiska naturalnego i w moralnym obowiązku ratowania zniszczonej przyrody.

Analogicznie w obszarze ekologicznego przeciwdziałania alkoholizmowi trzeba ratować osobę ludzką na wielu płaszczyznach. Wydaje się, że w dotychczasowej praktyce najlepszym sposobem w przeciwdziałaniu nadużywania alkoholu i tworzeniu atmosfery trzeźwości była profilaktyka (prewencja, interwencja, promocja zdrowia ${ }^{25}$ ). Jest ona dziedziną na pograniczu medycyny, socjologii i psychologii. W języku greckim prophylaktykos oznacza zapobieganie alkoholizmowi i obejmuje bardzo wiele strategii aktywności poszczególnych osób, grup i instytucji, różnych sposobów oddziaływania już na uzależnionego człowieka (aby nie pogłębić jego zniewolenia) lub ochrony go przed nałogiem ${ }^{26}$. Szereg autorów przedstawia mniej lub bardziej adekwatne programy profilaktyczne, które powinny uwzględniać przynajmniej działania prozdrowotne, elementy edukacji humanistycznej i społecznej, pomoc w zakresie umiejętności życiowych i działania na płaszczyźnie rodzinnej ${ }^{27}$. „Promocja zdrowia zorientowana jest na zdrowie w całej populacji, natomiast prewencja dąży do zminimalizowania prawdopodobieństwa wystąpienia choroby i zaburzeń i jest adresowana głównie do grup ryzyka". H. Sęk, Psychologia wobec promocji zdrowia, [w:] Psychologia zdrowia, red. I. Heszen-Niejodek, Warszawa 1997; cyt. za: L. Cierpiałkowska, Alkoholizm, dz. cyt., s. 214.

Por. tamże, s. 213-214. Może to być profilaktyka pierwszorzędowa, drugorzędowa lub trzeciorzędowa, w zależności od poziomu działań mających na celu zapobieganie uzależnieniom, od niespecyficznych (informacja, wczesne zapobieganie problemom) po interwencyjne (po wystąpieniu pierwszych symptomów alkoholizmu). Por. tamże, s. 214-215.

27 Por. K. Ostaszewski, Nowe idee w profilaktyce uzależnień, „Remedium” 3 (1993), s. 21; za: L. Cierpiałkowska, Alkoholizm, dz. cyt., s. 218. 
Najbardziej obiecująca i skuteczna jest profilaktyka w rodzinach i w szkołach, czego dowód stanowi istnienie zarówno wielu szkolnych programów profilaktycznych (najlepiej opisane są w tym temacie lata dziewięćdziesiąte XX wieku), jak i inicjatyw będących na pograniczu tych dwóch sfer życia dzieci i młodzieży ${ }^{28}$. Niestety początek XXI wieku i przemiany społeczno-kulturowe współczesnego świata, zwłaszcza obecny w krajach zachodnich kryzys tradycyjnej rodziny i wychowania szkolnego, w których problem alkoholizmu jest szczególnie jaskrawy i wymagający skutecznej prewencji, wskazują na coraz większe trudności w promocji trzeźwości i w profilaktyce nadmiernego spożywania napojów alkoholowych. Dochodzi do tego tzw. „paradoks prewencji alkoholowej”, który polega na tym, że szkody spowodowane nienałogowym, umiarkowanym piciem alkoholu są stosunkowo większe niż te wynikające $\mathrm{z}$ nałogowego picia substancji przez osoby uzależnione. Można zrozumieć, że budżety państw czerpią ogromne korzyści ze sprzedaży alkoholu (nawet gdy leczenie jest bardzo kosztowne finansowo i społecznie) i że nie każdy pijący jest nałogowym alkoholikiem. Trudno jednak pojąć fakt, że niemożliwe do zastosowania jest rozwiązanie profilaktycznie najprostsze i zarazem radykalne, czyli całkowita prohibicja, ponieważ alkohol był, jest i pewnie będzie trwałym elementem towarzyszącym ludzkości ${ }^{29}$. Czy przyszłość w tym zakresie ma szanse na odnowienie klasycznej profilaktyki i znalezienie nowych kierunków (np. ekologicznych) w zrozumieniu problemu alkoholizmu oraz bardziej skutecznych jego rozwiązań?

Badacze skuteczności profilaktyki alkoholizmu, np. szkolnych programów profilaktycznych (tzw. dwunastopunktowa lista Williama Hansena), wskazują na następujące kierunki:

- „całościowe podejście do problemu (projektowanie strategii działania uwzględniającej jak najwięcej elementów jednostkowych

28 Por. L. Cierpiałkowska, Alkoholizm, dz. cyt., s. 221-232.

29 Por. L. Cierpiałkowska, Alkoholizm, dz. cyt., s. 241-242. 
i kontekstowych, które mogą sprzyjać pozytywnym zmianom bądź je utrudniać, a nawet blokować);

- perspektywiczne podejście (projektowanie w przekonaniu, że efekty działań mają z reguły charakter długofalowy i że warto wybiegać daleko w przód swoją wyobraźnią, by takie długofalowe efekty zapewnić);

- wielopoziomowe podejście (zintegrowanie projektowanych działań na różnych poziomach - od globalnych strategii, tworzonych dla państwa czy regionu, aż po działania lokalne dla wąskiego odbiorcy);

- trafne ekologiczne podejście (projektowane dla określonych odbiorców, dopasowanie do ich indywidualnych potrzeb, problemów i możliwości, uwzględniający cały kontekst potencjalnych oddziaływań);

- interakcyjne podejście oparte na współpracy (projektowanie w interakcji z odbiorcą, realizatorem, ewaluatorem, sponsorem i środowiskiem, w którym mają zaistnieć zmiany);

- [...] sprawne finansowanie, dobra organizacja, fachowa wiedza i doświadczenie oraz ludzkie zaangażowanie [... $]^{30}$.

\section{Ekologia, profilaktyka i integralna prawda o człowieku w „trosce o wspólny dom”}

W cytowanym programie profilaktycznym Hansena pojawia się „ekologiczne podejście”, którego w szerokim ujęciu postulatów skutecznego, trwałego i całościowego zapobiegania alkoholizmowi nie można rozumieć tylko jako ekologii fizycznej, społecznej czy ekologii człowieka w powszechnym rozumieniu. Trzeba w ekologicznej profilaktyce alkoholu w większym stopniu uwzględnić konteksty osób: uzależnionej, towarzyszącej uzależnionemu i ponoszącej skutki uzależnienia 
innych; następnie uważać, żeby człowiek nadużywający alkoholu nie był traktowany jako część jakiegoś bezosobowego programu profilaktycznego albo pozostawiony samemu sobie ze swoim prywatnym problemem; oraz podkreślić, że jest on dla środowiska naturalnego i środowiska społecznego osobą szczególnej troski antropologicznej, etycznej i duchowej. Dopiero taka wielowymiarowa, zintegrowana z teologiczną i antropologiczną prawdą o profilaktyce i terapii alkoholowej ${ }^{31}$ ekologia ludzka pozwoli nie tylko na rozwiązanie problemu alkoholizmu konkretnych osób, ale będzie pomagać w zapobieganiu innym, „,nowym uzależnieniom [...], w których substancje chemiczne nie odgrywają żadnej roli”32.

Pytanie o relacje pomiędzy spożyciem alkoholu (nadużywaniem go) a bogactwem osoby ludzkiej, niekiedy uwikłanej w uzależnienia od substancji chemicznych (lub uzależnienia psychiczne wynikające z postępu współczesnej cywilizacji), znajduje odpowiedź $\mathrm{w}$ integralnej ekologii ludzkiej ujętej przyrodniczo, antropologicznie, etycznie i teologicznie, w której centrum jest skuteczna, trwała i całościowa profilaktyka osoby już uzależnionej i potencjalnie uzależnionej. Ta integralna ekologia ludzka znalazła swój wyraz w nauczaniu Kościoła katolickiego XX ${ }^{33}$ i XXI wieku, zwłaszcza w encyklice

31 „W kierunku integralności i rozwoju osoby. Pedagogika tomizmu konsekwentnego jako postulowana podstawa integralnej profilaktyki i terapii alkoholowej". K. A. Wojcieszek, Człowiek spotyka alkohol...: Filozoficzne podstawy wychowania do trzeźwości w ujęciu tomistycznym, Kraków 2010, s. 269-284.

32 C. Guerreschi, Nowe uzależnienia, tłum. A. Wieczorek-Niebielska, Kraków 2006, s. 23-24. „Ich przedmiotem są zachowania lub działania akceptowane społecznie. Pośród new addictions możemy wymienić: uzależnienie od gier hazardowych, Internetu, zakupów, pracy, seksu, pożywienia i więzi emocjonalnych". C. Guerreschi, Nowe uzależnienia, dz. cyt., s. 24. Pogłębiona analiza zintegrowanej, ludzkiej ekologii nowych uzależnień mogłaby być tematem kolejnego opracowania.

33 Jako przykład Magisterium Kościoła o ekologii ludzkiej w latach dziewięćdziesiątych ubiegłego wieku można przytoczyć nauczanie Jana Pawła II o „niebezpiecz- 
papieża Franciszka Laudato si'. W trosce o wspólny dom wydanej w $2015 \mathrm{roku}^{34}$.

Papieska ekologia ludzka nie odnosi się wprost do problemu uzależnień od alkoholu, chociaż encyklika wspomina o spożyciu narkotyków w krajach bogatych i o rosnącym wykorzystywaniu krajów ubogich, które produkują narkotyki, nawet kosztem degradacji środowiska naturalnego. Jednak trudno sobie wyobrazić wielowymiarową, zintegrowaną antropologicznie i teologicznie prawdę o profilaktyce i terapii alkoholowej bez ekologii ludzkiej, którą Franciszek buduje począwszy od ekologii środowiskowej, gospodarczej i społecznej przez ekologię kulturową i ekologię życia codziennego ${ }^{35}$. Ekologia ludzka, profilaktyka alkoholizmu, etyczna i teologiczna prawda o człowieku zawarta jest w praktycznych wskazaniach encykliki, aby „postawić na inny styl życia”, który przeciwstawi się „kompulsywnemu mechanizmowi konsumpcyjnemu” i nie znajdując dla ludzkości „nowego zrozumienia samej siebie” wobec „zbyt wielu środków [i] niewielu rachitycznych aspiracji” oraz braku "prawdziwego dobra wspólnego", uratuje człowieka i środowisko naturalne od „przemocy i wzajemnego zniszczenia" ${ }^{36}$.

nym niszczeniu środowiska ludzkiego” i potrzebie „ochrony warunków moralnych prawdziwej «ekologii ludzkiej»". Por. Jan PawełII, enc. Centesimus annus [dalej: CA], 1.05.1991, tekst polski, Watykan 1991, 38.

Por. Franciszek, enc. Laudato si` [dalej: LS], 24.05.2015, tekst polski, Kraków 2015.

Por. LS 137-155.

Por. LS 203-204. Szczegółowo każdej osobie ludzkiej, która staje wobec problemu alkoholu, można zadedykować przesłanie nadziei: „Jednak nie wszystko stracone, ponieważ człowiek zdolny poniżyć siebie aż do skrajności może również stawić czoło trudnościom, dokonać zwrotu i ponownie wybrać dobro, odrodzić się, niezależnie od narzuconych mu wszelkich uwarunkowań psychicznych i społecznych. Jest zdolny uczciwie spojrzeć na siebie, ujawnić swoją odrazę i podjąć nowe drogi ku prawdziwej wolności. Nie ma systemów, które całkowicie zniweczyłyby otwarcie na dobro, prawdę i piękno czy też zdolność do reakcji, jaką Bóg nieustannie wzbudza w głębi naszych serc. Każdego człowieka na tym świecie 
Ekologia ludzka wobec alkoholizmu to nie tylko styl życia w wolności od uzależnień, nie tylko ochrona środowiska naturalnego i ludzkiego od przemocy i zniszczenia. Z punktu widzenia antropologicznego (wolność, godność osoby) i etycznego (dobro, miłość, wspólnota) w zakresie profilaktyki istnieje również możliwość trzeźwości i abstynencji. Taka profilaktyka, także w formie interwencji, promocji zdrowia, jest jak najbardziej ludzkim elementem relacji człowiek - alkohol - środowisko. Encyklika Laudato si' zwraca uwagę na to, że ekologicznie trzeźwość osoby ludzkiej (niekoniecznie abstynencja, całkowita rezygnacja z napojów alkoholowych) spełnia postulat takiej „niezbędnej relacji życia człowieka z prawem moralnym, wpisanym w jego naturę, relację konieczną, aby można było stworzyć bardziej godne środowisko" ${ }^{37}$ wolności od uzależnień biologiczno-psychicznych i zniewoleń duchowych.

Pogłębionym sposobem profilaktyki alkoholizmu, w środowisku rodzinnym ${ }^{38}$, szkolnym, zawodowym, ale wzmocnionym ekologicznie, antropologicznie i teologicznie, jest również działanie społeczno-kościelne, zwłaszcza we wspólnotach Kościoła katolickiego (podobnie jak w mniejszej skali i w innych wspólnotach religijnych). Idee trzeźwości, abstynencji i wolności od uzależnień od dawna zresztą stanowiły nie tylko ważną część społecznych akcji przeciwalkoholowych, ale również duszpasterstwa, w którym ruch nowej ewangelizacji - ostatnio w ujęciu papieża Franciszka - wskazuje na Ewangelię zdolną uzdrowić zarówno obojętność religijną, „znikome uczestnictwo w Eucharystii, wierzenia fatalistyczne lub zabobonne,

proszę, by nie zapominał o swojej godności, której nikt nie ma prawa mu odbierać". LS 205.

37 LS 155.

38 To środowisko jest szczególnie ważne nie tylko z powodu rodzinnego charakteru ekologii ludzkiej (por. CA 39). Rodzina jest z jednej strony najbardziej narażona na skutki alkoholizmu (np. ojca rodziny), a z drugiej - trzeźwość i abstynencja w rodzinie stanowią najlepsze środowisko przeciwdziałania alkoholizmowi. 
skłaniające, by uciekać się do czarów", jak i wyzwolić od alkoholizmu i przemocy ${ }^{39}$.

Taka teologiczna forma profilaktyki alkoholowej jako odpowiedź na pytanie o relację między spożyciem alkoholu (nadużywaniem go) a ekologią ludzką wydaje się najbardziej adekwatnym sposobem pokonania trudności, jakie może mieć osoba ludzka z niszczącym wpływem uzależnienia, nie tylko od alkoholu, ale także np. od narkotyków. Jeśli w tę profilaktykę równocześnie integralnie włączy się nauki przyrodnicze, antropologię i etykę i podkreśli się godność i znaczenie osoby ludzkiej jako centralnego punktu świata stworzonego, to będziemy mieli dobry punkt wyjścia do zbudowania ludzkiej ekologii uzależnień (m.in. od alkoholu), która nie będzie niszczyć człowieka, ale go doskonalić i czynić nowym stworzeniem, dzieckiem Bożym „na obraz i podobieństwo Boga” (por. Rdz 1, 26-27).

Przede wszystkim profilaktyka, a następnie trzeźwość i abstynencja, są najważniejszymi elementami w relacji alkohol - ekologia ludzka, a profilaktyka alkoholizmu w szerokim kontekście antropologicznym, etycznym i teologicznym pozwala na tworzenie różnych pomocowych programów społecznych, wychowawczych i duszpasterskich. Szczególnie nauczanie Kościoła katolickiego daje szanse na odnowienie klasycznej profilaktyki i znalezienie nowych kierunków ekologii integralnej w zrozumieniu coraz bardziej palącego problemu różnych uzależnień (zwłaszcza od alkoholu) oraz bardziej skutecznych, kompleksowych i trwałych rozwiązań tych problemów. Najnowsza encyklika papieża Franciszka jest tego najlepszym przykładem. Jego propozycja (za cytowanym w Laudato si' ekumenicznym patriarchą Bartłomiejem I) ekologicznego wyzwolenia osoby ludzkiej od wszelkich uzależnień jest gotowa do natychmiastowego zastosowania, także w problemie alkoholu: 
abyśmy przeszli od konsumpcji do poświęcenia, od chciwości do wielkoduszności, od marnotrawstwa do zdolności dzielenia się, do ascezy, która „oznacza uczenie się dawania, a nie po prostu rezygnowania... Jest to sposób miłowania polegający na przechodzeniu od tego, czego chcę ja, do tego, czego chce Boży świat. Jest to wyzwolenie od strachu, chciwości i uzależnienia" ${ }^{\sharp 0}$.

40 Bartłomiej I, Wykład w klasztorze Utstein, Norwegia (23.07.2003); cyt. za: LS 9. 